\title{
EFFECTS OF ISOFLAVONES ON BEANY FLAVOR AND ASTRINGENCY OF SOYMILK AND COOKED WHOLE SOYBEAN GRAINS ${ }^{1}$
}

\author{
MERCEDES CONCÓRDIA CARRÃO-PANIZZI' , ADELAIDE DEL PINO BELÉIA ${ }^{3}$, \\ SANDRA HELENA PRUDÊNCIO-FERREIRA ${ }^{4}$, MARIA CRISTINA NEVES OLIVEIRA ${ }^{5}$, and KEISUKE KITAMURA ${ }^{6}$
}

\begin{abstract}
Flavor is the main limiting factor affecting soybean acceptability in the Occidental countries. The purpose of this study was to determine the effetcs of isoflavones on soybean flavor. Differences in beany flavor and astringency of soymilk and cooked whole soybean grains, prepared with cultivars IAS 5 and BR-36 (136 and $54 \mathrm{mg}$ of total isoflavones /100 g of sample, respectively) with pre-soaking and pre-heating of grains, were sensorially analised, by an unstructured category scale of ascending intensity. Differences in isoflavone contents for both soybean cultivars were maintained in the two products, despite the pre-treatments in the processing. Pre-soaking of grains intensified beany flavor in the soymilk, reducing the perception of astringency, which is caused by the aglucones that were developed in reduced amounts. The whole soybeans grains cooked under pressure $\left(1.5 \mathrm{kgf} / \mathrm{cm}^{2}\right.$ at $\left.127^{\circ} \mathrm{C}\right)$ presented reduced levels of isoflavones malonyl-glucosides. Due to thermal instability, these compounds were converted to conjugated glucosides, genistin and daidzin. In the cooked whole soybean grains, no aglucones were formed and consequently it was not possible to detect differences in astringency. Results suggest that pre-heating of grains promote better flavor in soybean products.
\end{abstract}

Index terms: Glycine max, cultivars.

\section{EFEITOS DOS ISOFLAVONÓIDES NO SABOR DE FEIJÃO CRU E NA ADSTRINGÊNCIA DO EXTRATO HIDROSSOLÚVEL DE SOJA E DOS GRÃOS INTEIROS COZIDOS}

\begin{abstract}
RESUMO - O sabor é o principal fator que limita a aceitabilidade da soja nos países ocidentais. O propósito deste estudo foi determinar os efeitos dos isoflavonóides sobre o sabor da soja. Diferenças no sabor de feijão cru e na adstringência do extrato hidrossolúvel de soja e dos grãos inteiros de soja cozidos, preparados com as cultivares IAS 5 e BR-36 (136 e $54 \mathrm{mg}$ isoflavonóides totais $/ 100 \mathrm{~g}$ de amostras, respectivamente), com pré-maceração e pré-aquecimento dos grãos, foram analisadas sensorialmente, conforme uma escala não estruturada de categoria de intensidade ascendente. As diferenças no teor dos isoflavonóides das duas cultivares foram mantidas nos dois produtos, apesar dos pré-tratamentos nos processamentos. Pré-maceração dos grãos intensificou o sabor de feijão cru nos extratos de soja, reduzindo a percepção de adstringência, que é causada por agliconas, que desenvolveram-se em quantidades reduzidas. Os grãos inteiros de soja cozidos sob pressão $\left(1,5 \mathrm{kgf} / \mathrm{cm}^{2}\right.$ a $\left.127^{\circ} \mathrm{C}\right)$ apresentaram teores muito reduzidos dos isoflavonóides malonil glicosídeos. Devido à alta temperatura, esses compostos foram convertidos nos glicosídeos conjugados daidzina e genistina. Nos grãos cozidos inteiros não houve formação de agliconas, e, conseqüentemente, não se percebeu diferença na adstringência. Os resultados sugerem que tratamentos que envolvem pré-aquecimento dos grãos favorecem a obtenção de produtos de soja com melhor sabor.
\end{abstract}

Termos para indexação: Glycine max, cultivares.

1 Accepted for publication on September 25, 1998.

2 Agronomist, Dra ${ }^{\mathrm{a}}$, Embrapa-Centro Nacional de Pesquisa de Soja, (CNPSo), Caixa Postal 231, CEP 86001-970 Londrina, PR, Brasil. E-mail: mercedes@ cnpso.embrapa.br

${ }^{3}$ Agronomist, Ph.D., Dep. de Tecnologia de Alimentos e Medicamentos, Universidade Estadual de Londrina, CEP 86051-970 Londrina, PR, Brasil.

\footnotetext{
${ }^{4}$ Pharmaceutist, Dr ${ }^{\mathrm{a}}$, Dep. de Tecnologia de Alimentos e Medicamentos, Universidade Estadual de Londrina.

${ }^{5}$ Mathematical, M.Sc., Embrapa-CNPSo.

${ }^{6}$ Biochemical, Ph.D., Agriculture, Forestry and Fisheries

Research Council’s Secretariat, Ministry of Agriculture,

Forestry and Fisheries, Tokyo 100, Japan.
} 


\section{INTRODUCTION}

Isoflavones have been related to anticancer properties of soybean. This fact increased the interest in soybean as a component of the human diet (Adlercreutz et al., 1991; Coward et al., 1993; Persky $\&$ Horn, 1995). The amount of isoflavones (two glucosides, genistin and daidzin, and their respective aglucones, genistein and daidzein) is variable among soybean cultivars, due to genetic and environmental factors (Eldridge \& Kwolek, 1983; Wang \& Murphy, 1994). Variability on the amount of isoflavones was also observed among different Brazilian soybean cultivars (Carrão-Panizzi \& Kitamura, 1995).

Processing techniques affect the type and level of isoflavones remaining in the final product. Traditional fermented products (miso, tempeh) contain high levels of daidzein and genistein (aglucones), while non fermented products, like dry grains, soymilk, soyflour, and tofu retain high concentrations of the unhydrolysed daidzin and genistin (Coward et al., 1993; Wang \& Murphy, 1994). Bitterness and astringency of soybean are caused by saponins and isoflavones, respectively (Huang et al., 1981; Okubo et al., 1992). The intensity of off-flavor in soymilk increases as the concentration of genistein and daidzein increases due to hydrolytic action of $\beta$-glucosidase on glucosidic isoflavone precursors (Matsuura et al.,1989). Boiling whole soybeans in a $0.25 \% \mathrm{NaHCO}_{3}$ solution effectively inhibit the hydrolysis of daidzin and genistin in soymilk, due to the inactivation of $\beta$-glucosidase (Ha et al., 1992). It should also be considered, however, that genistein is effective in preventing and inhibiting cancer processes (Peterson \& Barnes, 1991, 1993; Fotsis et al., 1993; Steele et al., 1995).

Flavor is the main limiting factor affecting soybean acceptability in the Occidental countries. Since isoflavones are one of the compounds involved with soybean flavor, and because a variability in isoflavone concentrations among soybean cultivars, was observed, this study was carried out to determine the effects of isoflavone on flavor of soymilk and whole cooked soybean grains.

\section{MATERIAL AND METHODS}

\section{Raw material}

Soybean cultivars IAS 5 and BR-36 sowed in Londrina, Paraná State, Brazil (latitude 2311' S), in 1993/94 with high and low isoflavone content (136 and $54 \mathrm{mg}$ of total isoflavones $/ 100 \mathrm{~g}$ of sample, respectively), were processed by pre-soaking and pre-heating treatments of grains in soymilk and whole cooked soybean grains.

\section{Soymilk preparation}

Soymilk with pre-heating treatment of grains was prepared according to Nelson et al. (1976), with the modifications introduced by Embrapa (1988). Clean and dry soybean $(162 \mathrm{~g})$ were placed directly into boiling water $(500 \mathrm{~mL})$ containing $0.25 \% \mathrm{NaHCO}_{3}$, for three minutes. After boiling, the water was discarded and the whole soybean grains were cooled with cold tap water. The grains were reblanched in boiling water $(1000 \mathrm{~mL})$ containing $0.05 \% \mathrm{NaHCO}_{3}$, for three minutes. The grains were then ground in a blender, for three minutes, and the slurry was cooked for ten minutes. Soymilk was extracted by filtration through a cotton cloth and boiled again.

Soymilk with pre-soaking treatment of grains was prepared according to the traditional oriental method. Soybean grains (162 g) were soaked in cold water for 16 hours at room temperature $\left(20^{\circ} \mathrm{C}\right)$. After soaking, water was discarded and the grains were then ground in a blender, for three minutes, in $1000 \mathrm{~mL}$ of cold water. The slurry was cooked for ten minutes, filtered and boiled.

\section{Cooked whole soybean grains preparation}

Cooked whole soybean grains with pre-soaking treatment, were prepared by soaking $100 \mathrm{~g}$ of grains in water, for 16 hours, at room temperature $\left(20^{\circ} \mathrm{C}\right)$. Soaked grains were cooked in $500 \mathrm{~mL}$ water for five minutes, under pressure $\left(1.5 \mathrm{kgf} / \mathrm{cm}^{2}\right.$ at $\left.127^{\circ} \mathrm{C}\right)$.

Cooked whole soybean grains without pre-soaking, were prepared by cooking dry grains $(100 \mathrm{~g})$ in $500 \mathrm{~mL}$ water, for 15 minutes, under pressure. Water was discarded and grains were prepared for sensorial analysis.

\section{Sensory evaluation}

Twenty one persons that were able to detect the basic tastes were selected to identify differences in bitterness. Triangle difference tests using caffein solution at $0.035 \%$, $0.070 \%$, and $0.140 \%$ concentrations, were offered in six combinations, of each solution. Twelve subjects ( 6 males and 6 females, age 25 to 40 years old) were selected 
according to sequential analysis defined as: $\alpha=0.01$; $\beta=0.05 ; \rho_{0}=0.35 ;$ and $\rho_{1}=0.65$ as suggested by Della-Modesta (1989). To test this bitterness in the soymilk, $5 \mathrm{mg}$ of genistein (Sigma, 4',5-7 trihydroxyisoflavone G6776) was added to $250 \mathrm{~mL}$ of soymilk prepared with the soybean cultivar BR-36, with pre-heating of grains. Tasters observed that soymilk with genistein was more astringent than bitter, and did not detect differences in bitterness. Because of that, just beany and astringency flavors, which were easier to detect were considered in the evaluation.

After training for perception of beany flavor and astringency, trainees were selected according to their ability to discriminate samples, reliability and agreement with the team, which were analysed statistically by ANOVA with two factors (samples and sessions), as suggested by Silva \& Damásio (1994). Trainees with greater F-sample values $(\mathrm{P} \leq 0.25)$ were selected for their ability to discriminate samples, while for reliability, trainees with lower $F$-sessions values $(\mathrm{P} \geq 0.05)$ were selected. To evaluate agreement of each trainee with the team, sample means of each trainee were compared with sample average of the team. After these analyses nine trainees were selected for the sensory analysis experiment.

An unstructured $9.0 \mathrm{~cm}$ intensity scale (Silva \& Damásio, 1994), was used to evaluated the sensory attributes, beany flavor and astringency. Coded samples of $25 \mathrm{~mL}$ of soymilk, at room temperature $\left(20^{\circ} \mathrm{C}\right)$, placed in small plastic cups were offered at random, individually and sequentially. Samples of four different treatments (two cultivars and two processing methods), were tasted in the each replicate session. Samples were presented one at a time because the flavor attributes, beany and astringency, were analysed in the same sample. Interstimulus rinsing protocol was observed during the evaluations.

Coded samples of $20 \mathrm{~g}$ of cooked grains, placed in small plastic cups, were offered to the tasters by using the same procedures observed with soymilk. Tests for soymilk and cooked whole grains were conducted in separate.

\section{High performance liquid chromatographic (HPLC) analysis}

Isoflavone content in the raw soybean grain, soymilk and in the cooked whole soybeans were determined by HPLC, according to Kudou et al. (1991) and Kitamura et al. (1991). Isoflavones were extracted from $100 \mathrm{mg}$ samples of freeze dried soymilk, ground raw and cooked whole soybeans, with $4.0 \mathrm{~mL}$ of $70 \%$ aqueous ethanol containing $0.1 \%$ acetic acid for one hour, at room temperature $\left(20^{\circ} \mathrm{C}\right)$. After centrifugation, $40 \mu \mathrm{L}$ of the supernatant was used directly for the HPLC analysis Analysis of isoflavones were performed on ODS commercially packed columns [Tosoh Corp., Tokyo; TKS gel ODS-80TM $(4.6 \times 250 \mathrm{~mm})]$. A $0.1 \%$ acidic acid solvent system was used with a linear gradient of acetonitrile, developed from $20 \%$ to $45 \%$ for 30 minutes. The solvent flow rate was $1.0 \mathrm{~mL} /$ minute, and UV absorption was measured at $260 \mathrm{~nm}$. Purified soybean genistin and daidzin (Kudou et al., 1991), were used as standards. Isoflavone content was calculated as milligrams per $100 \mathrm{~g}$ of dry matter.

\section{Statistical analysis}

Treatments were evaluated in a factorial experiment in a randomized complete design, according to Watts et al. (1992). Two soybean cultivars and two processing methods, were analysed by nine subjects, totalizing 36 treatment combinations replicated in five sessions for soymilk and three sessions for cooked whole soybean grains. According to the experiment design the following model was used: $Y_{i j k}=m+T_{i}+S_{j}+T^{*} S_{i j}+E_{i j k}$ where: $Y_{i j k}$ is the observations; $m$ is the effect of means; $T_{i}$ is the effect of treatments; $S_{j}$ is the effect of subjects; $T * S_{i j}$ is the effect of interaction Treatment $t_{i}$ and Subjects; $;$; and $E_{i j k}$ is the residual effect.

Before testing by ANOVA, the data were tested for normal distribution (Shapiro \& Wilk, 1965), homogeneity of variance (Hartley, 1940; Burr \& Foster, 1972), and model additivity (Tukey, 1949). A transformation of the data was applied to stabilize treatment variances and linear structure of the model (Hoaglin et al., 1992). Differences among treatment mean values were determined using Tukey's test at $\mathrm{P} \leq 0.05$ (Cochran \& Cox, 1957). Statistical Analysis System (SAS, 1995) and Sistema de Análise Estatística - SANEST (Zonta et al., 1982) were used to analyse the data.

\section{RESULTS AND DISCUSSION}

Soybean grains of cultivar IAS 5 had higher $(136 \mathrm{mg} / 100 \mathrm{~g})$ total isoflavone concentrations than cultivar BR-36 (54 mg/100 g) (Table 1), which were present mainly as $\beta$-glycosidic conjugates. Variation on isoflavones contents among soybean cultivars are influenced by genetics, crop year, and growth location (Wang \& Murphy, 1994; Carrão-Panizzi \& Kitamura, 1995). The climate, mainly temperature, during the seed development is the major factor determining the levels of isoflavone accumulation in the soybean grains (Kitamura et al., 1991; Tsukamoto et al., 1995). 
TABLE 1. Mean isoflavone contents (mg/100 $\mathrm{g}$ as is) in seeds samples of soybean cultivars IAS 5 e BR-36²

\begin{tabular}{lccccr}
\hline Cultivars & Daidzin & $\begin{array}{c}\text { Malonyl } \\
\text { daidzin }\end{array}$ & Genistin & $\begin{array}{c}\text { Malonyl } \\
\text { genistin }\end{array}$ & Total \\
\hline IAS 5 & 9.5 & 30.8 & 19.9 & 75.7 & 135.9 \\
BR-36 & 3.7 & 12.4 & 7.3 & 30.2 & 53.6 \\
\hline
\end{tabular}

${ }^{1}$ Mean values of two replicate analysis.

$\beta$-glycosidic conjugate isoflavones are the main forms found in the soybean grains. In soybean products, isoflavone composition and concentrations change according to the processing methods (Barnes et al., 1994). During soaking, $\beta$-glucosidase hydrolyses isoflavone glucosides (daidzin and genistin) to aglucones (daidzein and genistein) (Matsuura et al., 1989). Fermentation is another processing technique that hydrolyses the isoflavone glucosides. Non fermented soybean products showed lower levels of aglucones than fermented soybean foods (Coward et al., 1993; Wang \& Murphy, 1994). Isoflavones were present in the soymilk almost entirely as their $\beta$-glucosidic conjugates (daidzin and genistin), while the average contents of the aglucones, daidzein and genistein, were very small, $3.2 \mu \mathrm{g} / \mathrm{g}$ and $3.6 \mu \mathrm{g} / \mathrm{g}$ in one sample and, $1.1 \mu \mathrm{g} / \mathrm{g}$ and $1.3 \mathrm{mg} / \mathrm{g}$ in another sample, (Barnes et al., 1994). When soybean is processed at high temperatures $\left(>80^{\circ} \mathrm{C}\right)$, manolylated isoflavone glucosides which are thermally unstable are converted to the corresponding daidzin and genistin.

In this experiment, isoflavone $\beta$-glucoside conjugates were the major isoflavone compounds in soymilk and in cooked whole soybeans, as expected for non fermented soybean foods (Tables 2 and 3). Differences in total isoflavone contents observed in soybean cultivars IAS 5 and BR-36, were mantained despite the treatments (pre-soaking and pre-heating), in samples of freeze dried soymilk (Table 2). Soymilk prepared with the cultivar IAS 5 , by pre-heating treatment had $20.4 \mathrm{mg} / 100 \mathrm{~g}$ of total isoflavones, while by pre-soaking treatment had $16.5 \mathrm{mg} / 100 \mathrm{~g}$. Soymilk prepared with the cultivar BR-36 had $9.6 \mathrm{mg} / 100 \mathrm{~g}$, when prepared by pre-heating treatment; and $4.7 \mathrm{mg} / 100 \mathrm{~g}$, when prepared by pre-soaking treatment (Table 2). In spite of the low concentra- tions of aglucones found in all treatments, the level of aglucones (daidzein and genistein) increased twofold in the pre-soaked grain treatments, for both cultivars (Table 2).

Pre-soaking grains in water before soymilk extraction process intensified the beany flavor of soymilk, independently of the high or low isoflavone contents of soybean cultivars IAS 5 and BR-36 (Table 3). For the beany flavor data, because there was a dependence between logarithm of mean and logarithm of variance, it was applied a potency transformation $\left(\mathrm{y}^{0.70}\right)$, for higher efficiency on the treatment effects (Hoaglin et al., 1992). In this test, two subjects (tasters) were not able to accurately define the beany flavor, resulting in a significant interaction between subjects and treatments. In this case, according to Stone \& Sidel (1993), for statistical analyses, these two subjects were eliminated and the ANOVA was applied again with seven tasters.

The difference in astringency in the soymilk was not significant among treatments. Less intense astringency, however, was observed when grains of cultivar IAS 5 were not soaked (Table 3 ). The reduced amount of aglucones (daidzein and genistein) observed in the soymilk (Table 2) could be the probable explanation of the results of non significant differences in astringency among treatments.

Okubo et al. (1992) reported that isoflavones were more astringent than bitter, suggesting that saponins were responsible for the soybean bitterness. The same authors also observed that the bitter taste of caffein was different from bitter taste of soybean saponins. This bitterness difference was also observed by the tasters in the current study. Matsuura et al. (1989) found that isoflavone aglucones daidzein and genistein were responsible for the objectionable aftertaste in soymilk. 
TABLE 2. Mean values $( \pm \mathrm{E})$ of isoflavone content $(\mathrm{mg} / 100 \mathrm{~mL}$ dry weight) in soymilk extracted by two different processing methods (pre-soaking and pre-heating treatments of grains), from soybean cultivars IAS 5 and BR-36 ${ }^{1}$.

\begin{tabular}{|c|c|c|c|c|c|c|}
\hline Treatments & Daidzin & $\begin{array}{c}\text { Malonyl } \\
\text { daidzin }\end{array}$ & Daidzein & Genistin & $\begin{array}{c}\text { Malonyl } \\
\text { genistin }\end{array}$ & Genistein \\
\hline \multicolumn{7}{|c|}{ Cultivar IAS 5} \\
\hline Pre-soaking & $\begin{array}{c}0.39 \mathrm{a} \\
( \pm 0.05)\end{array}$ & $\begin{array}{l}7.38 \mathrm{ab} \\
( \pm 0.55)\end{array}$ & $\begin{array}{c}0.75 \mathrm{a} \\
( \pm 0.11)\end{array}$ & $\begin{array}{l}1.46 \mathrm{ab} \\
( \pm 0.09)\end{array}$ & $\begin{array}{l}5.37 \mathrm{ab} \\
( \pm 0.48)\end{array}$ & $\begin{array}{c}1.07 \mathrm{a} \\
( \pm 0.14)\end{array}$ \\
\hline Pre-heating & $\begin{array}{c}0.50 \mathrm{a} \\
( \pm 0.11)\end{array}$ & $\begin{array}{l}10.50 \mathrm{a} \\
( \pm 1.28)\end{array}$ & $\begin{array}{c}0.40 \mathrm{ab} \\
( \pm 0.07)\end{array}$ & $\begin{array}{c}2.51 \mathrm{a} \\
( \pm 0.31)\end{array}$ & $\begin{array}{c}6.00 \mathrm{a} \\
( \pm 0.86)\end{array}$ & $\begin{array}{c}0.53 \mathrm{~b} \\
( \pm 0.08)\end{array}$ \\
\hline \multicolumn{7}{|c|}{ Cultivar BR-36 } \\
\hline Pre-soaking & $\begin{array}{c}0.47 \mathrm{a} \\
( \pm 0.05)\end{array}$ & $\begin{array}{c}1.84 \mathrm{c} \\
( \pm 0.29)\end{array}$ & $\begin{array}{c}0.26 \mathrm{~b} \\
( \pm 0.03)\end{array}$ & $\begin{array}{l}0.29 \mathrm{~b} \\
( \pm 0.0)\end{array}$ & $\begin{array}{c}1.37 \mathrm{c} \\
( \pm 0.18)\end{array}$ & $\begin{array}{c}0.41 \mathrm{~b} \\
( \pm 0.10)\end{array}$ \\
\hline Pre-heating & $\begin{array}{c}0.65 \mathrm{a} \\
( \pm 0.09)\end{array}$ & $\begin{array}{l}4.76 \mathrm{bc} \\
( \pm 2.05)\end{array}$ & $\begin{array}{c}0.10 \mathrm{~b} \\
( \pm 0.10)\end{array}$ & $\begin{array}{l}1.11 \mathrm{ab} \\
( \pm 0.44)\end{array}$ & $\begin{array}{l}2.79 b c \\
( \pm 1.23)\end{array}$ & $\begin{array}{l}0.23 \mathrm{~b} \\
( \pm 0.07)\end{array}$ \\
\hline
\end{tabular}

${ }^{1}$ Means with different letters in the same column are significantly different (Tukey $\mathrm{P} \leq 0.05$ ).

TABLE 3. Mean values $( \pm \mathrm{SE})$ in sensory analysis of soymilk extracted by two different processing methods (pre-soaking and pre-heating treatments of grains), from soybean cultivars IAS 5 and BR-36, according to an unstructured $9.0 \mathrm{~cm}$ intensity scale ${ }^{1}$.

\begin{tabular}{lcc}
\hline Treatments & Beany flavor $^{2}$ & Astringency $^{3}$ \\
\hline BR-36 - Pre-soaking & $6.02 \mathrm{a}$ & $4.50 \mathrm{a}$ \\
& $( \pm 0.32)$ & $( \pm 0.36)$ \\
IAS 5 - Pre-soaking & $6.05 \mathrm{a}$ & $4.61 \mathrm{a}$ \\
& $( \pm 0.38)$ & $( \pm 0.34)$ \\
BR-36 - Pre-heating & $4.11 \mathrm{~b}$ & $4.00 \mathrm{a}$ \\
& $( \pm 0.43)$ & $( \pm 0.37)$ \\
IAS 5 - Pre-heating & $2.91 \mathrm{~b}$ & $2.87 \mathrm{~b}$ \\
& $( \pm 0.31)$ & $( \pm 0.28)$ \\
\hline
\end{tabular}

${ }^{1}$ Means followed by the same letters in the columns are not significantly different (Tukey P $\leq 0.05$ ).

${ }^{2}$ Mean values from seven tasters; for statistical analysis means were transformed by potency $\left(\mathrm{y}^{0.7}\right)$; the original data is presented.

${ }^{3}$ Mean values from nine tasters.

Results from this experiment suggested that the compounds daidzein and genistein in the soymilk were not present in sufficient amount (Table 2), to yield bitterness and astringency, and in this case, it was easier to perceive the beany flavor. Tango et al. (1984) observed that different soymilks obtained with different soybean cultivars were similar in astringency and bitter taste.
During soaking, lipoxygenase enzimes catalyze lipid oxidation developing undesirable carbonyl compounds which are responsible for the beany flavor (Rackis et al., 1972). The n-hexanal compound, formed during hydroperoxidase of linoleic acid (Matoba et al., 1985), remained as a major headspace organic compound in boiling $\mathrm{NaHCO}_{3}$ soaked soybeans (Ha et al., 1992). Beany flavor could also be present in the soybean grain before processing, as it was already observed by Rackis et al. (1970). Heat treatment is an effective method to inhibit objectionable flavor of soymilk, since it inactivates the enzymes lipoxygenase and $\beta$-glucosidase (Ha et al., 1992).

In the test of cooked whole soybean grains, malonyl isoflavones, which are heat-labile and unstable (Kudou et al., 1991; Coward et al., 1993; Cole \& Cousin Junior, 1994), were significantly reduced and converted to glucoside conjugates, daidzin and genistin (Table 4), as compared to the amounts of malonyl isoflavones in the raw soybean grains (Table 1). Barnes et al. (1994), also observed a significant reduction of malonyl conjugates, in soybean products prepared under pressure. Differences in isoflavone contents of cultivars IAS 5 and BR-36, were also maintained when grains were cooked under pressure, despite the pre-treatments.

Whole cooked soybean grains showed a similar beany flavor among treatments (Table 5). 
TABLE 4. Means $( \pm \mathrm{SE})$ of isoflavone contents $(\mathrm{mg} / 100 \mathrm{~g} \text { dry weight })^{1}$, in whole soybean grains of cultivars IAS 5 and BR-36, cooked under pressure $\left(1.5 \mathrm{kgf} / \mathrm{cm}^{2} \text { at } 127^{\circ} \mathrm{C}\right)^{2}$.

\begin{tabular}{|c|c|c|c|c|c|c|}
\hline Treatments & Daidzin & $\begin{array}{l}\text { Malonyl } \\
\text { Daidzin }\end{array}$ & Total & Genistin & $\begin{array}{l}\text { Malonyl } \\
\text { Genistin }\end{array}$ & Total \\
\hline \multicolumn{7}{|c|}{ Cultivar IAS 5} \\
\hline Pre-soaking & $\begin{array}{c}58.9 \mathrm{a} \\
( \pm 3.90)\end{array}$ & $\begin{array}{c}0.9 \mathrm{a} \\
( \pm 0.21)\end{array}$ & $\begin{array}{c}59.8 \mathrm{a} \\
( \pm 4.08)\end{array}$ & $\begin{array}{c}130.9 \mathrm{a} \\
( \pm 6.00)\end{array}$ & $\begin{array}{c}1.3 \mathrm{a} \\
( \pm 0.09)\end{array}$ & $\begin{array}{c}133.5 \mathrm{a} \\
( \pm 6.59)\end{array}$ \\
\hline Pre-heating & $\begin{array}{l}65.6 \mathrm{a} \\
( \pm 2.14)\end{array}$ & $\begin{array}{c}1.9 \mathrm{a} \\
( \pm 1.04)\end{array}$ & $\begin{array}{c}67.5 \mathrm{a} \\
( \pm 3.17)\end{array}$ & $\begin{array}{c}139.1 \mathrm{a} \\
( \pm 10.13)\end{array}$ & $\begin{array}{c}1.2 \mathrm{a} \\
( \pm 0.08)\end{array}$ & $\begin{array}{c}142.2 \mathrm{a} \\
( \pm 10.26)\end{array}$ \\
\hline \multicolumn{7}{|c|}{ Cultivar BR-36 } \\
\hline Pre-soaking & $\begin{array}{c}17.4 \mathrm{~b} \\
( \pm 2.36)\end{array}$ & $\begin{array}{c}0.8 \mathrm{a} \\
( \pm 0.77)\end{array}$ & $\begin{array}{c}18.2 \mathrm{~b} \\
( \pm 1.64)\end{array}$ & $\begin{array}{c}32.2 \mathrm{~b} \\
( \pm 3.76)\end{array}$ & $\begin{array}{c}0.9 \mathrm{~b} \\
( \pm 0.09)\end{array}$ & $\begin{array}{l}34.3 \mathrm{~b} \\
( \pm 2.94)\end{array}$ \\
\hline Pre-heating & $\begin{array}{c}26.4 \mathrm{~b} \\
( \pm 6.26)\end{array}$ & $\begin{array}{c}1.9 \mathrm{a} \\
( \pm 1.05)\end{array}$ & $\begin{array}{c}28.3 \mathrm{~b} \\
( \pm 5.67)\end{array}$ & $\begin{array}{c}52.8 \mathrm{~b} \\
( \pm 7.18)\end{array}$ & $\begin{array}{c}0.9 \mathrm{~b} \\
( \pm 0.10)\end{array}$ & $\begin{array}{c}53.5 \mathrm{~b} \\
( \pm 7.18)\end{array}$ \\
\hline
\end{tabular}

${ }^{1}$ HPLC analysis were made with an ODS-80 TS column.

${ }^{2}$ Means followed by the same letters in the column are not significantly different (Tukey $\mathrm{P} \leq 0.05$ ).

TABLE 5. Mean values $( \pm \mathrm{SE})$ of sensorial analysis of whole soybean grains of cultivars IAS 5 and BR-36, cooked under pressure $\left(1.5 \mathrm{kfg} / \mathrm{cm}^{2}\right.$ at $127^{\circ} \mathrm{C}$ ) according to an unstructured 9.0 cm intensity scale ${ }^{1}$.

\begin{tabular}{lcc}
\hline Treatments & Beany flavor $^{2}$ & Astringency $^{3}$ \\
\hline BR-36 - Pre-soaking & $2.74 \mathrm{~b}$ & $1.97 \mathrm{a}$ \\
& $( \pm 0.38)$ & $( \pm 0.31)$ \\
IAS 5 - Pre-soaking & $3.58 \mathrm{ab}$ & $2.87 \mathrm{a}$ \\
& $( \pm 0.44)$ & $( \pm 0.41)$ \\
BR-36 - Pre-heating & $3.91 \mathrm{ab}$ & $2.82 \mathrm{a}$ \\
& $( \pm 0.49)$ & $( \pm 0.40)$ \\
IAS 5 - Pre-heating & $4.63 \mathrm{a}$ & $3.06 \mathrm{a}$ \\
& $( \pm 0.53)$ & $( \pm 0.45)$ \\
\hline
\end{tabular}

${ }^{1}$ Means followed by the same letters in the columns, are not significantly different (Tukey $\mathrm{P} \leq 0.05$ ).

2 Mean values obtained with nine tasters.

${ }^{3}$ For statistical analysis mean values were transformed by potency $\left(\mathrm{y}^{-0.26}\right)$; the original data is presented.

According to Hoaglin et al. (1992), because there was a dependence between logarithm of mean and of variance, a potency transformation $\left(\mathrm{y}^{-0.26}\right)$ was applied on astringency data (Table 5), for higher efficiency on the treatment effects.

Whole cooked soybean grains were not broken before soaking, and probably, lipoxygenase enzyme did not interact with the substrate to develop beany flavor as observed by Nelson et al. (1976). The cultivar BR-36, with pre-soaking treatment had the lowest beany flavor. Astringency of cooked whole soybean grains was the same for all treatments (pre-heating and pre-soaking) (Table 5). This result suggests that at high temperature b-glucosidase was inactivated and did not form aglucones, which are related to astringency (Okubo et al., 1992). Absence of aglucones could not cause differences among treatments for astringency, suggesting that aglucones are the compounds related to that sensorial attribute.

\section{CONCLUSIONS}

1. Differences in isoflavone contents between IAS 5 and BR-36 are maintained in soymilk and whole cooked soybean grains, despite the processing treatments.

2. The aglucone genistein is formed in the soymilk in reduced amounts and does not affect flavor. Pre-soaking treatment of grains intensifies beany flavor in the soymilk reducing the perception of astringency, which is caused by genistein.

3. When whole soybeans grains are cooked under pressure, malonyl glucosides is converted to the correspondent conjugated glucosides (daidzin and genistin). In this case, the aglucones (daidzein and genistein) is not formed and no differences on astringency is observed.

4. Soybean flavor is complex involving several different compounds, and pre-heating is an effective method to obtain soybean products with better flavor. 


\section{ACKNOWLEDGEMENT}

To Mr. Celso Fratias and Mr. Adriano A. do P. Lima for the field work and sample preparation; to J.L.T. da Silva, A.C.F. Mendes, N.M.S. Scarpelin, T. Fagundes, E.M. Nakamura, M. de Aquino, Z. Miranda, L.M. Chueire, M. da S. Pires, I. Soldório, J.J. da Silva, O. Ferreira, A. Carneiro, F. E. Paro, C. S. Aligleri and I. C. Silva for the sensorial analysis. We are also grateful to A. R. Panizzi and N. Neumaier for their critical reading of this manuscript; to the National Agriculture Research Center for allowing to use Legume Breeding Laboratory facilities; to Conselho Nacional de Desenvolvimento Científico e Tecnológico (CNPq) for providing finantial support to the trip to Japan and to Embrapa for allowing to realize this work.

\section{REFERENCES}

ADLERCREUTZ, H.; HONJO, H.; HIGASHI, A.; FOTSIS, T.; HAMALAINEN, E.; HASEGAWA, T.; OGAWA, H. Urinary excretion of lignans and isoflavonoid phytoestrogens in Japanese men and women consuming a traditional Japanese diet. American Journal of Clinical Nutrition, v.54, p.1093-1110, 1991.

BARNES, S.; KIRK, M.; COWARD, L. Isoflavones and their conjugates in soy foods: Extraction conditions and analysis by HPLC-mass spectrometry. Journal of Agricultural and Food Chemistry, v.42, p.2466-2474, 1994.

BURR, I.W.; FOSTER, L.A. A test for equality of variances. West Lafayette: University of Purdue, 1972. 26p. (Mimeo Series, 282).

CARRÃO-PANIZZI, M.C.; KITAMURA, K. Isoflavone content in Brazilian soybean cultivars. Breeding Science, v.45, p.295-300, 1995.

COCHRAN, W.G.; COX, G.M. Experimental designs. New York: Willy, 1957. 601p.

COLE, K.; COUSIN JUNIOR, S.L. Size exclusion chromatography of soybean proteins and isoflavones. Journal of Agricultural and Food Chemistry, v.42, p.2713-2720, 1994
COWARD, L.; BARNES, N.C.; SETCHELL, K.D.R.; BARNES, S. Genistein, daidzein, and their $\beta$-glycoside conjugates: Antitumor isoflavones in soybean foods from American and Asian diets. Journal of Agricultural and Food Chemistry, v.41, p.1961-1967, 1993.

DELlA-MODESTA, R.C. Análise sensorial de alimentos e bebidas. Rio de Janeiro: Embrapa-CTAA, 1989. 72p.

ELDRIDGE, A.; KWOLEK, W. Soybean isoflavones: Effect of environment and variety on composition. Journal of Agricultural and Food Chemistry, v.31, p.394-396, 1983.

EMBRAPA-Centro Nacional de Pesquisa de Soja (Londrina, PR). Delícias da soja: um cardápio nutritivo. Rio de Janeiro: Globo, 1988. 86p.

FOTSIS, T.; PEPPER, M.; ADLERCREUTZ, H.; FLEISCHMANN, G.; HASE, T.; MONTESANO, R.; SCHWEIGERER, L. Genistein, a dietary-derived inhibitor of in vitro angiogenesis. Proceedings of the National Academy of Sciences of the United States of America, Serie Medical Sciences, v.90, p.2690-2694, 1993.

HA, E.Y.W.; MORR, C.V.; SEO, A. Isoflavone aglucones and volatile organic compounds in soybeans: Effects of soaking treatments. Journal of Food Science, v.57, p.414-417, 1992.

HARTLEY, H.O. Testing the homogeneity of a set of variances. Biometrika, v.31, p.249-255, 1940.

HOAGLIN, D.C.; MOSTELLER, F.; TUKEY, J.W. Análise exploratória de dados: técnicas robustas. Lisboa: Salamandra, 1992. 446p.

HUANG, A.; HSIEH, O.A.L.; CHANG, S.S. Characterization of the non volatile minor constituents responsible for the objectionable taste of deffated soybean flour. Journal of Food Science, v.47, p.19-23, 1981.

KITAMURA, K.; IGITA, K.; KIKUCHI, A.; KUDOU, S.; OKUBO, K. Low isoflavone content in early maturing cultivars, so called summer-type soybeans (Glycine $\max (\mathrm{L}$.) Merrill). Japanese Journal of Breeding, v.41, p.651-654, 1991.

KUDOU, S.; FLEURY, Y.; WELTI, D.; MAGNOLATO, D.; UCHIDA, T.; KITAMURA, K.; OKUBO, K. Malonyl isoflavone glycosides in soybeans seeds (Glycine $\max ($ L.) Merrill). Agricultural and Biological Chemistry, v.55, p.2227-2233, 1991.

Pesq. agropec. bras., Brasília, v.34, n.6, p.1045-1052, jun. 1999 
MATOBA, T.; HIDAKA, H.; NARITA, H.; KITAMURA, K.; KAIZUMA, N.; KITO, M. Lipoxygenase-2 isoenzyme is responsible for generation of n-hexanal in soybean homogenate. Journal of Agricultural and Food Chemistry, v.33, p.852-855, 1985.

MATSUURA, M.; OBATA, A.; FUKUSHIMA, D. Objectionable flavor of soymilk developed during the soaking of soybeans and its control. Journal of Food Science, v.54, p.602-605, 1989.

NELSON, A.I.; STEINBERG, M.P.; WEI, L.W. Illinois process for preparation of soymilk. Journal of Food Science, v.41, p.57-51, 1976.

OKUBO, K.; IJIMA, M.; KOBAYASHI, Y.; YOSHIKOSHI, M.; UCHIDA, T.; KUDOU, S. Components responsible for the undesirable taste of soybean seeds. Bioscience Biotechnology Biochemistry, v.56, p.99-103, 1992.

PERSKY, V.; HORN, L.V. Epidemiology of soy and cancer: perpectives and directions. Journal of Nutrition, v.125, p.709S-712S, 1995.

PETERSON, G.; BARNES, S. Genistein and Biochanin A inhibit the growth of human prostate cancer-cells but not epidermal growth factor receptor tyrosine autophosphorylation. The Prostate, v.22, p.335-345, 1993.

PETERSON, G.; BARNES, S. Genistein inhibition of the growth of human breast cancer-cells: independence from estrogen receptors and the multi-drug resistance gene. Biochemical and Biophysical Research Communications, v.179, p.661-667, 1991.

RACKIS, J.J.; HONIG, D.H.; SESSA, D.J.; MOSER, H.A. Lipoxygenase and peroxidase activities of soybeans as related to flavor profile during maturation. Cereal Chemistry, v.49, p.586-597, 1972.

RACKIS, J.J.; HONIG, D.H.; SESSA, D.J.; STEGGERDA, F.R. Flavor and flatulence factors in protein products. Journal of Agricultural and Food Chemistry, v.18, p.977-982, 1970.

SAS INSTITUTE. SAS proprietary software release 6.09. Cary, NC, 1995.
SHAPIRO, S.S.; WILK, M.B. An analysis of variance test for normality. Biometrika, v.52, p.591-611, 1965.

SILVA, M.A.A.P. da; DAMÁSIO, M.H. Curso de análise sensorial descritiva. Campinas: Fund. Tropical de Pesquisas e Tecnologia "André Tosello", 1994. $58 \mathrm{p}$.

STEELE, V.E.; PEREIRA, M.A.; SIGMAN, C.C.; KELLOFF, G.J. Cancer chemoprevention agent development strategies for genistein. Journal of Nutrition, v.125, p.713S-716S, 1995.

STONE, J.L.; SIDEL, H. Sensory evaluation practices. San Diego: Academic Press, 1993. 338p. (Food Science and Technology, A Series of Monographs).

TANGO, J.S.; SANTOS, L.C.; TURATTI, J.M.; MORI, E.E.M.; SHIROSE, I; YOTSUYANAGI, K. Caracterização de algumas cultivares de soja para produção de extrato protéico. Boletim do Instituto Tecnologia de Alimentos, Campinas, v.21, p.157-182, 1984.

TSUKAMOTO, C.; SHIMADA, S.; IGITA, K.; KUDOU, S.; KOKUBUN, M.; OKUBO, K. Factors affecting isoflavone content in soybean seeds: changes in isoflavones, saponins, and composition of fatty acids at different temperatures during seed development. Journal of Agricultural and Food Chemistry, v.43, p.1184-1192, 1995.

TUKEY, J.W. One degree of freedom for non-additivity. Biometrics, v.5, p.232-242, 1949.

WANG, H.; MURPHY, P. Isoflavone content in commercial soybean foods. Journal of Agricultural and Food Chemistry, v.42, p.1666-1673, 1994.

WATTS, B.M.; YLIMAKI,G.L.; JEFFERY, L.E.; ELIAS, L.G. Métodos sensoriales básicos para la evaluación de alimentos. Ottawa,Canada: CIID, 1992. 170p.

ZONTA, E.P.; MACHADO, A.A.; SILVEIRA JÚNIOR, P. Sistema de Análise Estatística-SANEST (Software). Registro na SEI No 066060. Pelotas: UFPel, 1982. 